\title{
How external stakeholders drive the green public procurement practice? An organizational learning perspective
}

Junqi Liu and Yanlin Ma

School of Economics and Management, Southwest Jiaotong University, Chengdu, China

Andrea Appolloni

Department of Management and Law, University of Rome Tor Vergata, Rome, Italy and School of Management, Cranfield University, Bedford, UK, and

\section{Wenjuan Cheng}

Department of Management and Law, University of Rome Tor Vergata, Rome, Italy

\begin{abstract}
Purpose - This study aims to uncover the black box of the influence mechanism between external stakeholder drivers and green public procurement practice, and meanwhile to explore the moderating role of administrative level in this process. Green public procurement (GPP) has been widely implemented. Existing literature has found that external stakeholder drivers can affect public sectors' GPP practice, however, the definition of its connotation is still unclear, and how external stakeholders affect GPP practice has remained a black box.

Design/methodology/approach - After defining the major external stakeholders, this study develops a multiple mediation theoretical model using survey data from 142 Chinese local public sectors. It aims to uncover the black box of the influence mechanism between external stakeholder drivers and GPP practice and meanwhile explore the moderating effect of administrative levels in this process.

Findings - The results show that external stakeholder drivers have a positive relationship with GPP practices. The knowledge of GPP implementation policies and the knowledge of GPP benefits can both mediate this relationship. This study also finds that the administrative level of public sectors can positively moderate the mediating effect produced by the knowledge of GPP implementation policies and negatively moderate the mediation effect produced by the knowledge of GPP benefits.

Social implications - Local governments need to better encourage public sectors to implement GPP. Managers of public sectors need to pay attention to organizational learning to acquire relevant knowledge on GPP.

Originality/value - This study makes a theoretical contribution to a better understanding of the influence mechanism for GPP practice. This study also provides comparisons of GPP implementation policies between China and European Union.
\end{abstract}

Keywords Green public procurement (GPP), Stakeholders, Organizational learning,

Triple bottom line (TBL), Moderated mediation, Procurement policy

Paper type Research paper

This study is supported by The National Social Science Fund of China [Grant number: 15XZZ011] and MOE (Ministry of Education in China) Project of Humanities and Social Science [Grant number: 18YJC630218]. The authors express their gratitude to Prof Alessandro Ancarani and anonymous Reviewer for the constructive comments and helps on earlier versions of this paper.

Conflicts of interest. None.

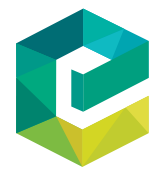




\section{Introduction}

Environment-friendly outputs and sustainability through public procurement are one of the important social goals of public procurement (De Giacomo et al., 2019), also known as green public procurement (GPP). As international organizations (Hasselbalch et al., 2014), developed regions (Ahsan and Rahman, 2017; Tsai, 2017), developing regions (Geng and Doberstein, 2008; Ho et al., 2010) have widely implemented GPP, a sufficient practical foundation is laid for the topic of GPP practice. Therefore, this topic has further received extensive attention in academia (Cheng et al., 2018).

One of the core issues of GPP practice is to explore why and how public sectors can better implement GPP (Sönnichsen and Clement, 2020). Most existing studies focus on the internal factors that motivate organizations to better practice GPP (Grandia and Voncken, 2019), such as knowledge (Liu et al., 2019a; Testa et al., 2016), training (Aragão and Jabbour, 2017), top management support/transformational leadership (Walker and Brammer, 2016), larger organizations (Testa et al., 2012) and higher administrative levels (Liu et al., 2019b). However, obstacles to GPP (Delmonico et al., 2018; Walker et al., 2008), such as cost/budget issues (McMurray et al., 2014), priority conflicts (Brammer and Walker, 2011) and supplier acquisition issues (Dou et al., 2014), make it difficult for public sectors to rely on internal motivation to better implement GPP (Alhola et al., 2019). The external motivation of organizations also plays a crucial role.

Among the external factors, the legislation of central government is undeniably important (Ahsan and Rahman, 2017; Oruezabala and Rico, 2012; Thomson and Jackson, 2007). This may be because the main difference between public and private procurement is that public procurement is restricted and constrained by regulations (Lian and Laing, 2004; Liu et al., 2019b; Loader, 2018). However, in the case that the current relevant regulations are voluntary (European Commission, 2016; Testa et al., 2012) or a prior (Ministry of Finance, 2017; Standing Committee of the National People's Congress, 2014), the promoting role of the regulations is limited because of their lack of mandatory power (Mélon, 2020).

In this case, stakeholders of public sectors, especially external stakeholders, become more crucial drivers. Existing studies also noted this issue and conducted related research (Roman, 2017; Walker and Brammer, 2009; Zhu et al., 2013a). They found that external stakeholder drivers can significantly affect GPP practice. However, the current definitions of the major external stakeholders of GPP in public sectors are still unclear. Also, how external stakeholders affect an organization's GPP practice has remained a black box. Particularly, the role of organizational knowledge in this black box is worth discussing. When analyzing the Chinese context, an important structural factor concerns the administrative level (Liu et al., 2019b). And the administrative level represents the ability to allocate resources (Wang and Yeh, 2019). Therefore, it may play an important moderating role in the relation between external stakeholders and GPP practice. In response to these gaps, we raise the following research questions $(R Q s)$ :

$R Q 1$. What are the major external stakeholders in driving public sectors' GPP practice?

$R Q 2$. From the perspective of organizational learning, what is the influence mechanism between external stakeholders and GPP practice? Does the organizational knowledge play a mediating role?

RQ3. Does the administrative level moderate the mediation process?

To answer these $R Q s$, we focus on GPP practice in public sectors and develop a multiple mediation theoretical model from the perspective of organizational learning. This study aims to uncover the black box of the influence mechanism between external stakeholder 
drivers and GPP practice, and meanwhile to explore the moderating role of administrative level in this process. This study has two major theoretical contributions. On the one hand, from the perspective of organizational learning theory, it deconstructs the black box between external stakeholder drivers and GPP practice, which adds to the existing knowledge (Roman, 2017; Walker and Brammer, 2009; Zhu et al., 2013a), and responds to the call of Liu et al. (2019a). On the other hand, it explores the knowledge of $G P P$ benefits based on triple bottom line (TBL) and administrative level with Chinese characteristics, which expands the research of Liu et al. (2019b).

The rest of this study is structured as follows. Section 2 is organizational context. Section 3 explores the theory and puts forth the hypotheses. Section 4 explains the methodology and the analysis. Section 5 includes discussion of the results. Section 6 presents the conclusions of this study. In Appendix 1, this study provides a comparison between new and previous GPP implementation policies in China. In Appendix 2, this study provides GPP implementation policies comparisons between China and European Union (EU).

\section{Organizational context}

The main purpose of this section is to define the types of organizations discussed in this study.

As a procurement policy tool, GPP needs to be implemented by procurement entities. Similarly, in the relevant academic research of GPP, it is necessary to have specific research objects. The research on GPP in developed countries can not only discuss the concept of public organizations as a whole (Roman, 2017) but also subdivide public organizations, for example, from the perspective of government (Preuss, 2009), education sector (Bala et al., 2008) and public health sector (Ahsan and Rahman, 2017).

At present, the relevant GPP practice research in China mainly takes the government as the research object (Liu et al., 2019b; Xu et al., 2016; Zhu and Geng, 2013). However, according to the "Government Procurement Law of the PRC" (Standing Committee of the National People's Congress, 2014), there are three types of public organizations (contract entities) in procurement activities, namely government (such as finance bureau), public institution (such as public hospitals or schools) and public group organization (such as women's federation) (Figure 1). In other words, to explore the practice issue of GPP in China, in the selection of public organizations (research objects), we should not only consider government but also explore public institutions and group organizations.

In this study, the two kinds of public organizations, public institutions and group organizations, are discussed as the study object (Figure 1). The reasons are as follows. On the one hand, government is the sector with administrative management functions, while public institutions and group organizations are sectors that provide social services (Brødsgaard, 2002). Public institutions and group organizations are subject to the administrative management of the government (in this study, the government is regarded as

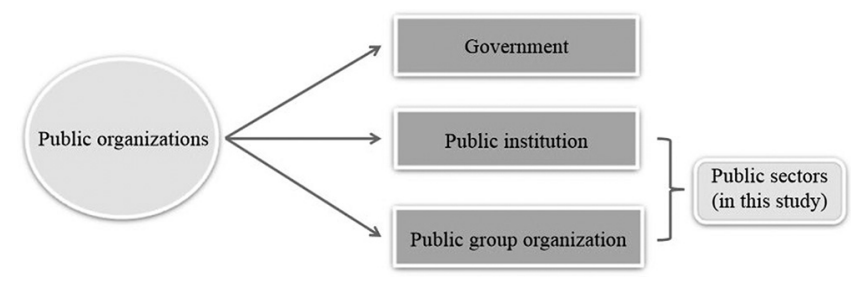

Figure 1. Composition of public organizations in China 
JOPP

Figure 2.

Numbers of three types of public organizations (contracting entities) in the last five years in China (2013-2017) one of their major external stakeholders), and their motivation for green procurement is different from that of the government. However, there is a lack of relevant research (Liu et al., 2019b; Xu et al., 2016; Zhu and Geng, 2013).

On the other hand, according to the data of the National Bureau of Statistics of the PRC (National bureau of statistics, 2020), the number of public institutions and group organizations in China is significantly higher than that of government agencies (Figure 2), leading to a more widespread presence in society. To a certain extent, this shows that the number and amount of green procurement carried out by public institutions and groups may be much higher than that of governments, and their procurement preference will have a significant impact on the success of GPP. Therefore, it is quite important to explore the GPP practice of public institutions and group organizations.

To sum up, the public organizations discussed in this study are defined as public institutions and group organizations, and "public sector" will be used to refer to these two types of contract entities.

In addition, the discussion of public organizations also needs to clarify the administrative level of public organizations. The administrative level in western society mainly refers to a region, while in china each sector has an administrative level because of the historical issue leftover from the planned economy. For example, China's public schools and public hospitals also have different administrative levels (Brown and Theoharides, 2009; Du, 2016; Du et al., 2020; Pepper, 1982). Public organizations in China have six administrative levels (Figure 3), which can be divided into national and local categories. The national level refers to the central governments/public sectors, and the local level refers to the local governments/public sectors at or below the provincial administrative level. As this study focuses on the local level, we sometimes use the concept of "local public sectors." Differences in administrative levels represent differences in the political power and the ability of resources acquisition and allocation (Wang and Yeh, 2019; Wei, 2015). Higher-level public sector has high political power and adequate financial funds, manpower and other resources, thus it may encounter fewer obstacles in practice (Liu et al., 2019b).

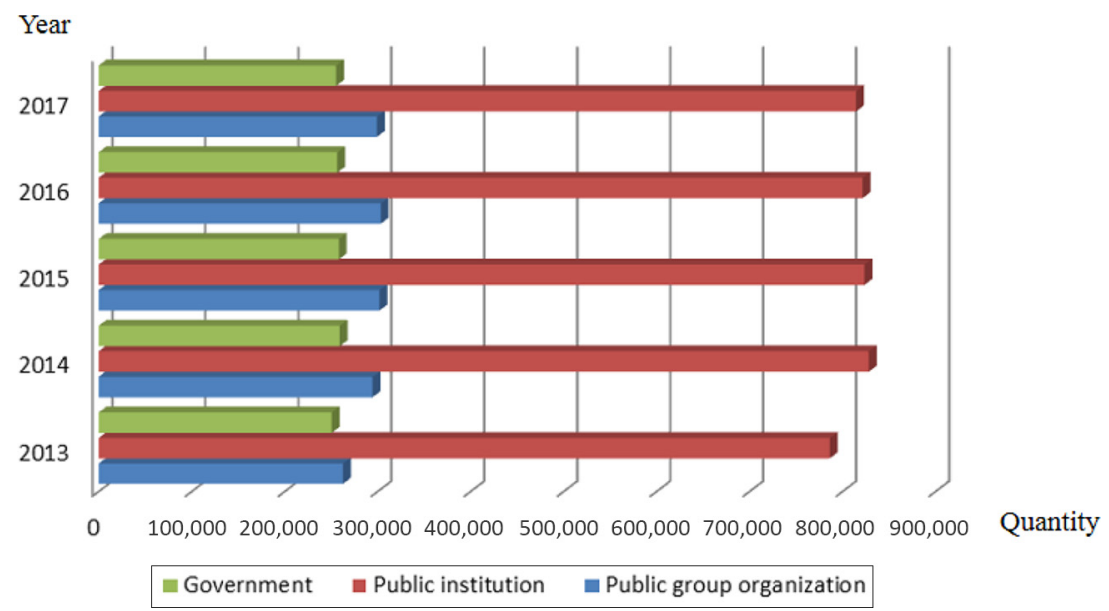


As an important theory of strategic management (Adams et al., 2011), stakeholder theory refers to any group or individual who can affect or is affected by the achievement of an organization's objectives (Freeman, 1984). Stakeholders are often divided into internal and external stakeholders (Dai et al., 2014; Testa et al., 2018). For a business organization, internal stakeholders (e.g. the management team and employees) can control its key resources. External stakeholders (e.g. shareholders, governments, social groups, etc). can affect its practices through financial investment, coercive pressures and the ability to mobilize public opinions (Sarkis et al., 2010).

Although both external and internal stakeholders are important in the environmental field (Yu and Ramanathan, 2015), external stakeholders are considered to be more capable of driving organizations' environmental practices (Walker et al., 2008). In both developed and developing countries, for public sectors, GPP is a procurement strategy mainly driven by external forces (European Commission, 2016; Ho et al., 2010; Liu et al., 2019a, 2019b; Ministry of Finance, 2019; Testa et al., 2012). Therefore, in the GPP field, existing studies paid more attention to external stakeholders (Ahsan and Rahman, 2017; Roman, 2017; Zhu et al., 2013a). Next, we discuss three major external stakeholders of GPP practice in public sectors: local government, green leading suppliers and society.

3.1.1 Local government as a stakeholder. Regarding the government as an external stakeholder, the existing studies mainly analyze it from the perspective of central government legislation (top-down) (Ahsan and Rahman, 2017; Oruezabala and Rico, 2012). However, with the background that the regulations are voluntary (European Commission, 2016; Testa et al., 2012) and a priority (Ministry of Finance, 2017; Standing Committee of the National People's Congress, 2014), the legislation of the central government does not have much coercive effect on GPP practice. Especially in China, the relevant laws and regulations of GPP are scattered and general (Liu et al., 2019a), which makes promoting the implementation of GPP by local public sectors mainly the work of local governments (Wang et al., 2020a). In fact, local public sectors mainly deal with local governments. Local governments hold a much higher stake in local public sectors than the central government. Hence, we next explore the driving of the GPP practice of public sectors by local governments from three management aspects: budgets, personnel management and rules and supervision.

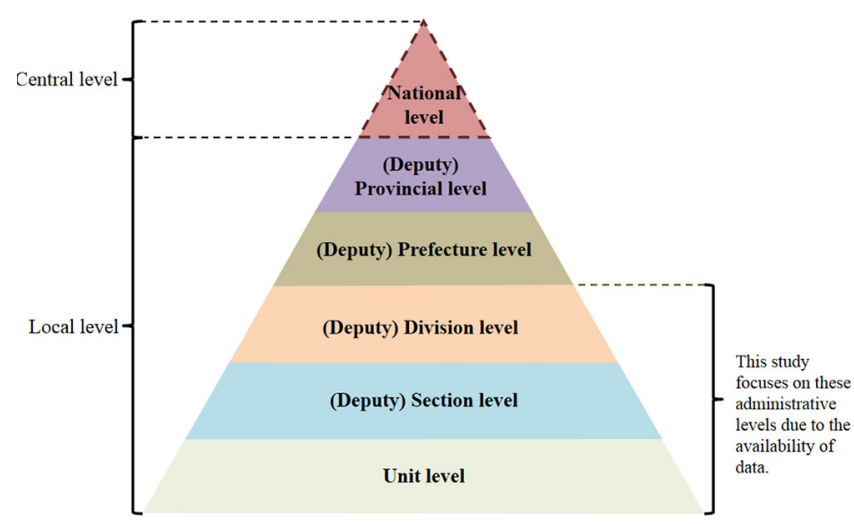

Figure 3.

Brief introduction of administrative levels of public organizations in China 
First, local governments can incentivize GPP practice through funding. Just as shareholders exert influence on enterprises through investment (Sarkis et al., 2010), local governments, as a source of financial funds for public sectors (Mimba et al., 2013), also have an important influence on their activities (Gelderman et al., 2017). Lack of sufficient funds is a significant challenge and obstacle for public sectors to implement GPP (Ahsan and Rahman, 2017; McMurray et al., 2014). Since most of the funding of public sectors come from local government budgets (Wong, 2009), the preference and support of local governments for GPP in the financial budgets will drive the GPP practice of public sectors to a greater extent.

Second, local government can conduct personnel management in public sectors by appointing top management. The top management of Chinese public sectors are often appointed directly by local governments, rather than the elected. Therefore, the top management/leaders attach great importance to the expectations of local governments. Also, the top management is a strong internal political force in an organization (Giunipero et al., 2012) and holds the necessary status (Dai et al., 2014; Liu et al., 2020). Therefore, when local governments encourage GPP practice, in cases where priority conflicts with other policy tools (Brammer and Walker, 2011; Delmonico et al., 2018), public sectors are also likely to act according to the will of local governments.

Third, local governments can promote GPP practice through local rules and supervision. Local rules are different from national regulations. They tend to be more in line with local conditions, and more detailed. Local rules show the importance that local governments attach to GPP. In addition, local governments have a supervisory role in public sectors' GPP practice (Ministry of Finance, 2017). Without government supervision, public sectors may buy the wrong (green-washing) green products (Testa et al., 2018), which may undermine the enthusiasm of GPP practice.

3.1.2 Green leading suppliers as stakeholder. Suppliers are important external stakeholders in the procurement practice of public sectors (Standing Committee of the National People's Congress, 2014) and green suppliers are important external stakeholders for public sectors to implement GPP. Green suppliers refer to environmentally conscious suppliers, whose designing, packaging, logistics and other activities conform to the relevant environmental criteria (Bala et al., 2008; Giannakis et al., 2019; Govindan et al., 2015; Lee et al., 2009; Zhu et al., 2013a). GPP practice is inseparable from green suppliers. Public sectors need to select green suppliers, or even their collaboration, for getting the environmental benefits that green suppliers deliver through the supply chain. Thus, public sectors can improve environmental performance and achieve the expected environmental outcomes in society (Grandia and Meehan, 2017; Kannan et al., 2013). Without the participation of green suppliers, it would be difficult to implement GPP (Ahsan and Rahman, 2017).

Green leading suppliers, are green suppliers with larger market share (Nakao, 1993), top technical and innovation skills (Oruezabala and Rico, 2012). Green leading suppliers are more capable and possess the resources and channels to influence the procurement preferences of public sectors. Hence, this study considers that green leading suppliers are one of the major external stakeholders of public sectors. Despite green leading suppliers being the main participant in GPP - to the best of our knowledge - little to no research explores this issue from the perspective of green leading suppliers as a driver/motivator (Roman, 2017). Public procurement is a large market (Reijonen et al., 2016). As a demandside policy tool (Cheng et al., 2018), GPP can increase the demand for green products or services. Thus, it becomes an important market and growth point for green leading suppliers. If public sectors do not actively implement GPP, it may lead to a stagnation, even a decline in the market performance of green leading suppliers, which will further affect their financial performance. Therefore, to improve their market share and financial performance, and to find an outlet for green technology innovation, the green leading 
suppliers will motivate the GPP practice of public sectors. They have the required capability and resources and can motivate public sectors through multiple channels, such as firms/ industry alliances (e.g. association of industry and commerce) and multi-level Chinese People's Political Consultative Conference (CPPCC) proposals.

3.1.3 Society as a stakeholder. Society is also an important external stakeholder that drives GPP in public sectors. Society consists mainly of the public, non-governmental organizations (NGOs) and the media (Sarkis et al., 2010; Zhu et al., 2013a). The public is usually the end consumers of public procurement, whose expectations are a GPP driver (Ahsan and Rahman, 2017). Meanwhile, NGOs also play an important role in motivating GPP implementation (Akenroye et al., 2013). With the increasing influence of environmental NGOs in China (Zhu et al., 2013a), their driving force to GPP has also gradually increased. Due to media reports (Boykoff and Boykoff, 2007), their own feelings and functional requirements, the public and the NGOs pay more attention to GPP practice (Walker and Brammer, 2012). From this perspective, the expectations and requirements of society will also drive GPP practice.

When the public sector perceives the pressure from local government, it actively communicates with the local government to understand the GPP rules and budgets set by local government. After understanding, the public sector can make arrangements and plans for green procurement to avoid budget cuts (Mimba et al., 2013), loss of political status and violations of local rules. When the public sector perceives the pressure from green leading suppliers, it may make sufficient use of the procurement budget to meet the expectations of green leading suppliers, which aims to avoid stagnation and increased proposals resulting from the decline in the financial performance of green suppliers. When the public sector perceives the pressure of society, it actively considers the expectations of society to avoid the decline of its credibility and the damage to its image (Gunningham et al., 2004; Liu et al., 2020), thus promoting the implementation of GPP.

In summary, the major external stakeholders, namely, local government, green leading suppliers and society, can drive the GPP practice of public sectors. Although this study defines three major external stakeholders that influence the GPP practice of public sectors, referring to the existing research (Zhu et al., 2013a), this study refers to them as a single concept (construct) that represents external drivers, that is, external stakeholders. More importantly, by regarding external stakeholders as a concept, we can better analyze the follow-up influence mechanism, that is, the analysis of mediation and moderation effects. This is also supported by existing research (Sarkis et al., 2010). Therefore, we propose the following hypothesis:

\section{H1. External stakeholder drivers are positively associated with GPP practice.}

\subsection{Organizational learning theory}

Knowledge is considered as an important resource of an organization (Lindner and Wald, 2011; Wang et al., 2012). If an organization's core competitiveness is its knowledge (Wang et al., 2012), then organizational learning is the best way to cultivate its core competitiveness (Hefner, 2014). Organizational learning can be defined as a change of organizational knowledge, which is a function of experiences (Fiol and Lyles, 1985). Recently, changes in public sectors have driven the need for researching organizational learning in public sectors (Dodgson, 1993; Rashman et al., 2009).

The process of organizational learning (how to derive and absorb knowledge from experiences) is an important issue of discussion for OLT research (Crossan et al., 1999; De Giacomo et al., 2019; Sheng and Chien, 2016). However, why organizations should gain this experience and knowledge is equally important. Argote and Miron-Spektor (2011) suggest 
that organizational experience is affected by environmental context. The reason for organizational learning is to adapt to the environment, especially to the changeable or turbulent environment (Fiol and Lyles, 1985). In other words, organizational learning can be regarded as the environmental background affecting organizational knowledge through experiences, which then further affects organizational behaviors or practices (Argote and Miron-Spektor, 2011). Environmental background refers to factors outside the boundaries of an organization. In this study, the external stakeholders of public sectors are considered as the environmental background. Organizational knowledge, as the core of OLT, will be divided into two types of knowledge in this study, namely, knowledge of GPP implementation policies and knowledge of GPP benefits.

3.2.1 Organizational learning theory and knowledge of green public procurement implementation policies. OLT believes that changes in the external environment will motivate the need for organizational learning (Dodgson, 1993; Rashman et al., 2009). With the popularity of GPP, the emphasis on GPP by external stakeholders has changed the external environment in which the public sector faces, leading the public sector to learn what GPP is and how to promote its implementation. GPP policies can provide clear guidance for GPP practice (European Commission, 2016) (Appendix 1 and Appendix 2). Knowledge of GPP policies is equivalent to "know-how" (Liu et al., 2019a). If there is a lack of knowledge of GPP policies, the public sector may not know how to properly implement GPP practices (Testa et al., 2016). Thus, the public sector's response to external stakeholders is hindered. Therefore, when the public sector faces pressure from external stakeholders, it is necessary to learn knowledge of GPP implementation policies.

Knowledge of GPP implementation policies is being widely discoursed (Ahsan and Rahman, 2017). Academics (McMurray et al., 2014; Walker and Brammer, 2009) and practitioners (Bouwer et al., 2011) find the lack of GPP knowledge as an obstacle to GPP practice. If public sectors lack knowledge of GPP policies, GPP may be seen as unnecessary bureaucratic red tape (Zhu et al., 2013a). Empirical research from developed (Grandia, 2016; Testa et al., 2012, 2016) and developing countries (Liu et al., 2019b; Nadeem et al., 2017) also shows that the more public sectors know about GPP policies, the more they can promote GPP practice.

External factors can indirectly motivate an organization's environmental practices by affecting its internal factors (Dai et al., 2014). OLT posits that changes in the external environment will promote the need for organizational learning (Dodgson, 1993; Rashman et al., 2009). Driven by the external environment of external stakeholders, GPP policies are the knowledge that public sectors need to possess (Günther and Scheibe, 2006; Testa et al., 2012). Although external stakeholders can drive GPP practice, the possibility of eventual practice still depends to some extent on knowledge (Zhu et al., 2013a). According to OLT, the knowledge acquired via organizational learning can provide the capability for organizational change (Cavaleri, 2004; Inkpen, 1998). To respond successfully to external stakeholders' drive for GPP practice, public sectors need to have knowledge of GPP policies. In summary, external stakeholders will drive public sectors' GPP practice by affecting their understanding of GPP implementation policies. Therefore, we propose the following hypothesis:

H2a. The knowledge of GPP implementation policies possessed by public sectors mediates the positive relationship between external stakeholder drivers and GPP practice.

3.2.2 Organizational learning theory and knowledge of green public procurement benefits. Public sectors should not only have the knowledge of GPP implementation policies but also an understanding of the benefits GPP brings (European Commission, 2019). According to 
OLT, the external stakeholders as the external environment background of public sectors are an important driving force for them to acquire knowledge (Rashman et al., 2009), especially the knowledge of GPP benefits. Specifically, when the public sectors perceive the expectations and appeals of external stakeholders to GPP, they are likely to think about why external stakeholders do so, and then learn the benefits of practicing GPP. In addition, the public sectors can learn about the environmental benefits and other benefits of GPP from motivating methods of external stakeholders such as media reports and public opinion (Zhu et al., 2013a). This process can also be seen as a process for organizations to explore new knowledge (Crossan et al., 2011). Eventually, organizations will store the learned knowledge as their resource (Argote and Miron-Spektor, 2011). Therefore, public sectors are motivated by external stakeholders to acquire knowledge of GPP benefits through learning.

Existing research believes that understanding the benefits of GPP is important because it offers "why to do GPP" (Liu et al., 2019a). Conversely, the lack of knowledge of the benefits will limit GPP implementation (Ahsan and Rahman, 2017; Burja, 2009). To study GPP benefits more systematically, we introduce the concept of TBL, namely, the environment (earth), economy (profit) and society (people) (Elkington, 1998; Govindan et al., 2013). Although TBL originates from firms, this concept can also be applied to public sectors (Ihamäki et al., 2014; Wahid, 2012). This study will study GPP benefits from the three TBL perspectives.

First, environment refers to the environmental responsibility that organizations need to fulfill, that is, caring for and protecting the environment (Elkington, 1998; Prajogo et al., 2012). Environment is the most important and significant goal of GPP practices (European Commission, 2019). GPP can reduce greenhouse gas emissions and carbon footprint, and improve the efficiency of resource utilization, so as to achieve the goals of environmental sustainability. This has been supported by empirical studies (Cerutti et al., 2016; Rietbergen and Blok, 2013; Tsai, 2017).

Second, economy refers to the economic responsibilities of organizations, such as reducing costs and increasing profits. As public sectors themselves are less involved in production, their economic responsibilities are mainly to reduce costs and guide consumption and production. Reducing costs does not mean blindly lowering prices but ensuring value for money (VfM) (Grandia, 2018). The initial purchase cost of green products is higher, but their use, maintenance and disposal costs are lower. Therefore, the life cycle cost (LCC) may be lower (Liu et al., 2019a). From the perspective of spillovers (Simcoe and Toffel, 2014), the GPP implementation of public sectors can promote sustainable consumption and production (Cheng et al., 2018; Pacheco-Blanco and Bastante-Ceca, 2016). Public sectors play the role of "leaders" and guide the public to green consumption (Geng and Doberstein, 2008). This can create or expand the market for green companies, thus promoting the production of green products and improving the green market (Bala et al., 2008; Li and Geiser, 2005).

Third, society refers to the social responsibilities, that is, developing stakeholder relations and social image. To achieve sustainability, organizations should consider not only economic and environmental issues but also the impact of their activities on society (Hollos et al., 2012; Prajogo et al., 2012). GPP can bring environmental benefits (Diófási-Kovács and Valkó, 2015) and social benefits (Burja, 2009; Rüdenauer et al., 2007). GPP helps public sectors to maintain their relationships with various stakeholders and to develop a better public image (Pacheco-Blanco and Bastante-Ceca, 2016; Rüdenauer et al., 2007). In summary, public sectors are more likely to improve GPP practice when they have knowledge of the environmental, economic and social benefits of GPP.

External drivers are crucial but internal factors should also not be ignored (Liu et al., 2020; Sarkis et al., 2010). Even if external stakeholders impose a driving force on an organization's implementation of environmental practices, the organization's response to 
this driving force may be heterogeneous (Darnall, 2006). In the GPP practice of public sectors, this heterogeneity can be explained by the organization's lack of knowledge of GPP benefits. Based on OLT, the cognition and knowledge of an organization will affect its actions (Crossan et al., 2011). When there is a lack of understanding of GPP benefits, public sectors may consider GPP implementation to be a formalized procedure and there is a risk of reducing procurement efficiency (Wang et al., 2020b), which will hinder GPP practice. To sum up, external stakeholder drivers will in turn promote GPP practice by affecting public sectors' understanding of GPP benefits. Therefore, we propose the following hypothesis:

H2b. The knowledge of GPP benefits possessed by public sectors mediates the positive relationship between external stakeholder drivers and GPP practice.

\subsection{Administrative level of public sectors}

Administrative levels show a hierarchy established by the state for the purpose of administrative management (Hassan and Sheely, 2017). Many countries have administrative subdivisions, for example, America (Jenks and Wright, 1993), Ghana (Ayee, 2013), Vietnam (Malesky, 2009), Indonesia (Pierskalla, 2016) and China (Zhang et al., 2020). China used to be a planned economy with a high degree of centralization, its long-term administrative hierarchy is deep-rooted and more representative (Wei, 2015). The administrative levels of local public sectors in China can be divided into unit level, section (township), division (country/district), prefectural and provincial levels (Chan, 2010). Usually, the administrative level corresponds to its power (Li et al., 2015). Public sectors with higher administrative levels generally have greater political power and/or capacity for acquiring resources (Wang and Yeh, 2019; Wei, 2015). Considering the differences brought by administrative levels to public sectors, they may be related to GPP practice (Liu et al., 2019b).

According to OLT, changes in the external environment drive the need for organizational learning (Dodgson, 1993; Rashman et al., 2009). When public sectors are driven by external stakeholders, they will learn and acquire knowledge of GPP implementation policies. However, the degree of the positive relationship between external stakeholder drivers and the organization's knowledge of GPP implementation policies may be affected by administrative levels. Public sectors with higher administrative levels can gain greater political power (Wang and Yeh, 2019), and have the right to formulate rules or propose higher requirements (Li et al., 2015; Wei, 2015). Driven by external stakeholders, higher-level public institutions are more likely to develop appropriate GPP implementation rules according to their actual situation and impose higher requirements on GPP (Ministry of Finance, 2019), rather than in accordance with national GPP implementation policies. In contrast, lower-level public sectors have less opportunity to develop their own GPP implementation rules and are more likely to rely on knowledge of existing GPP implementation policies. Therefore, the higher the administrative level of public sectors is, the weaker the positive relationship between external stakeholder drivers and knowledge of GPP implementation policies is. Thus, $H 3 a$ is proposed:

H3a. The relationship between external stakeholder drivers and knowledge of GPP implementation policies is negatively moderated by administrative levels.

Public sectors' knowledge of GPP implementation policies will stimulate GPP practice (Liu et al., 2019a; Testa et al., 2012, 2016), but the final level of GPP practice is also related to contextual factors (Zhu et al., 2013a), such as the administrative level. As mentioned earlier, the higher the administrative level of public sectors that implement GPP is, the lesser 
reliance on national GPP implementation policies there is. In other words, the higher the level of public sectors is, the weaker the positive relationship between the knowledge of GPP implementation policies and GPP practice is. Therefore, $H 3 b$ is proposed:

$H 3 b$. The relationship between knowledge of GPP implementation policies and GPP practice is negatively moderated by administrative level.

Based on $H 3 a$ and $H 3 b$, we assume that the relationship between external stakeholder drivers and knowledge of GPP implementation policies, as well as the relationship between knowledge of GPP implementation policies and GPP practice, will be negatively moderated by administrative level. Therefore, this study argues that for public sectors with higher administrative levels, the knowledge of GPP implementation policies may have a weaker mediating effect on the relationship between external stakeholder drivers and GPP practice:

H3. The administrative level of public sectors negatively moderates the mediating effect of knowledge of GPP implementation policies on the relationship between external stakeholder drivers and GPP practice.

The administrative level of public sectors will not only bring differences in political power but also differences in the acquisition and allocation of resources (Wang and Yeh, 2019; Wei, 2015). Administrative level of a public sector will affect its ability to acquire financial funds, manpower, and other resources (Henderson et al., 2009). Firm size is similar to the administrative level. For firms, a larger size means that it has sufficient resources (Lin and Ho, 2011) and even has slack resources (Nybakk et al., 2011). In contrast, the green practices of small size firms are easily limited by insufficient resources (Dai et al., 2014).

Existing literature found that firm size can moderate the relationship between external and internal factors (Krammer, 2013). In view of the similar role of administrative level and firm/organization size (Liu et al., 2019b), we argue that the administrative level of public sectors may also moderate the relationship between external stakeholder drivers and the knowledge of GPP benefits. In this regard, we speculate that lower-level public sectors, driven by external stakeholders, need to know more about the benefits of GPP because of their limited financial resources. For example, one of the significant obstacles to the implementation of GPP is the higher initial procurement cost (Ahsan and Rahman, 2017). Because lower-level public sectors do not have sufficient funds, they need to have a deeper understanding of the knowledge of GPP benefits (such as lower LCC) to have the motivation to overcome this difficulty. In other words, the lower the administrative level of public sectors is, the stronger the positive relationship between external stakeholder drivers and the knowledge of GPP benefits is. Therefore, $H 4 a$ is proposed:

H4a. The relationship between external stakeholder drivers and knowledge of GPP benefits is negatively moderated by administrative level.

In addition to financial factors, the implementation of GPP is also vulnerable to a lack of other resources. As a relatively new procurement method, GPP implementation requires more resources from public sectors (such as green supplier selection process) (Liu et al., 2019b). As a resource, manpower plays a very important role in the implementation of GPP (Liu et al., 2019a; Testa et al., 2012). Higher-level public sectors have more manpower, and it may be easier for them to implement GPP. Lower-level public sectors usually have a higher workload and limited manpower resources (General Office of the CPC Central Committee, 2019), so it may be more difficult for them to implement GPP. For lower-level public sectors, when they do not fully understand the benefits of GPP, they may not be willing to spend 
extra manpower on GPP practice. That is, they need to rely more on knowledge of GPP benefits to implement GPP. Therefore, the lower the level of public sectors is, the stronger the positive relationship between the knowledge of GPP benefits and GPP practice is:

H4b. The relationship between knowledge of GPP benefits and GPP practice is negatively moderated by administrative level.

Based on $H 4 a$ and $H 4 b$, this study assumes that the relationship between external stakeholder drivers and knowledge of GPP benefits, as well as the relationship between knowledge of GPP benefits and GPP practice, will be negatively moderated by administrative level. Therefore, this study argues that for public sectors with higher administrative levels, the knowledge of GPP benefits may have a weaker mediating effect on the relationship between external stakeholder drivers and GPP practice:

H4. The administrative level of public sectors negatively moderates the mediating effect of knowledge of GPP benefits on the relationship between external stakeholder drivers and GPP practice.

The theoretical model of this study is shown in Figure 4 below.

\section{Methodology and analysis}

\subsection{Survey sample}

Referred to Churchill (1979) and followed the practice of Dai et al. (2014). After a literature review, we selected the appropriate items, then directly use them or slightly modify them as the measurement items of variables. After completing the preliminary questionnaire, we invited three professors in the field of management and six $\mathrm{PhD}$ students and government procurement experts to evaluate its clarity, readability and content validity. According to their feedback, we have revised the questionnaire.

We chose Mianyang and Chengdu in Sichuan province of China as survey area. Because the procurement staff in public sectors are not easily accessible, the snowball sampling is used (Heckathorn, 2002). It is commonly used in the studies of public sectors (Brammer and Walker, 2011; Walker and Brammer, 2009; Zhu et al., 2013a). We send questionnaires to public procurement officials (leader, deputy leader, office directors and procurement specialists)

Figure 4 .

Theoretical model

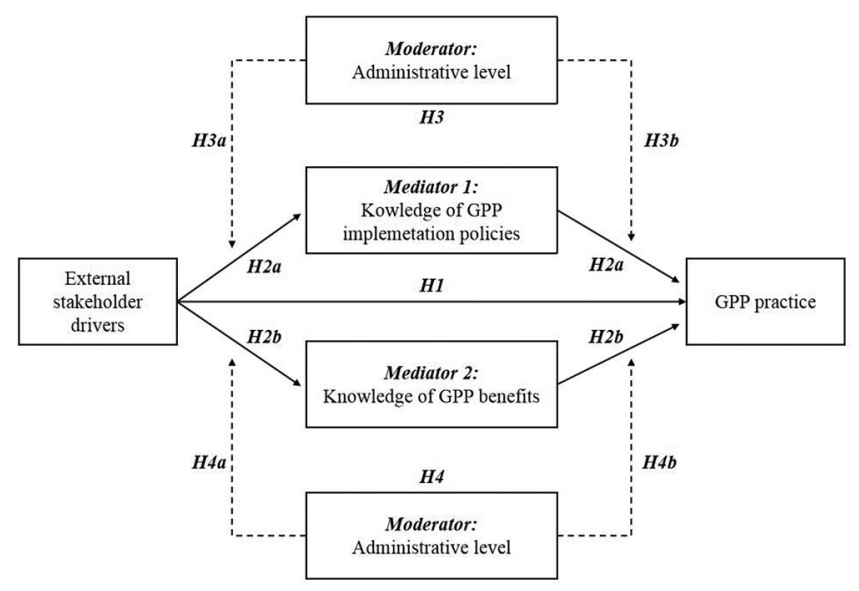


through familiar managers/directors from the government and public sectors. Then they were asked to continue sending questionnaires to appropriate participants in their social network. The questionnaires were allocated and recollected in November 2019 through online means.

To reduce the common rater effect (Zhu et al., 2013b), besides the type of public sectors (public institution or group organization) and the industry of public sectors (education, health and others) as mandatory items, the respondents can choose not to provide other personal information and public sector information. In this way, anonymity will be guaranteed. Due to the sampling strategy, the questionnaire recovery rate cannot be accurately estimated (Walker and Brammer, 2009). A total of 155 questionnaires were collected in this study, of which 142 were valid and the effective rate was $91.61 \%$. The attributes for public sectors under investigation are as follows. According to the types of public sectors, there were 125 public institutions, accounting for $88.03 \%$. There were 17 groups, accounting for $35.92 \%$. According to their industries, there were 51 education industries, accounting for $35.92 \%$ and 31 health industries, accounting for $21.83 \%$. Then there were 60 other industries, accounting for $42.25 \%$.

\subsection{Measures and measurement model testing}

This study measured six variables/constructs. The first variable/construct is external stakeholder driver (ESH). Referring to Zhu et al. (2013a), this study measures the three different external stakeholders of public sectors with a single construct, namely, external stakeholders, which is helpful to better analyze the subsequent influence mechanism (Sarkis et al., 2010). The remaining five variables/constructs are knowledge of GPP implementation policies [KGIP, Liu et al. (2019b)], knowledge of GPP benefits [KGB, Dou et al. (2014), Geng and Doberstein (2008); Prajogo et al. (2012)], practice level of GPP [PLG, Roman (2017), Walker and Brammer (2012), meanwhile, to better adapt to the Chinese background, the items are modified according to procurement experts' suggestions] and administrative level [AL, Liu et al. (2019b)]. Meanwhile, three control variables were used, namely, the industries of public sectors (education (Con1), health (Con2), others), the types of public sectors (public institution (Con3), group organization) and the areas of public sectors [Mianyang (Con4), Chengdu]. In addition, the respondents' job satisfaction [JS, Wanous et al. (1997)] was taken as a marker variable. The questions and measurement items are shown in Appendix 3.

Next, we tested Cronbach's-alpha and used confirmatory factor analysis (CFA) (Fornell and Larcker, 1981). According to the theoretical structure, second-order CFA was used to calculate the factor loadings, and their component reliability (CR) and average variance extraction (AVE) (Table 1). Meanwhile, we calculated the correlation coefficient between each variable and the square root of AVE (SRAVE) to check the discriminant validity (Table 2).

From Tables 1-2, the Cronbach's-alpha exceeded 0.7, the internal correlations are significant and CR exceeded 0.6. In addition, AVE also exceeded 0.5. This indicates that reliability and convergent validity are good (O'Leary-Kelly and Vokurka, 1998; Fornell and Larcker, 1981). Meanwhile, the correlation coefficient did not exceed the minimum SRAVE, indicating that the discriminant validity is good (Hair et al., 2010).

In addition, we calculated the model fit indexes of the measurement model $\left(\chi^{2}=133.147\right.$; $\mathrm{df}=107 ; \chi^{2} / \mathrm{df}=1.244 ; \mathrm{CFI}=0.973 ;$ TLI $=0.966 ;$ RMSEA $\left.=0.042\right)$, reached the standards (Kline, 2005) indicating that the measurement model fits well with the data. These show that the variables and scales have good reliability and validity.

\subsection{Common method variance}

We used marker variable (MV) (Lindell and Whitney, 2001) to detect CMV. There are two methods of correlation-based MV. One is to select smallest correlation coefficient as 
JOPP

\begin{tabular}{|c|c|c|c|c|c|c|}
\hline Variables & $1^{\text {st }} \mathrm{SFL}$ & $2^{\text {nd }} \mathrm{SFL}$ & $t$ & $\mathrm{CA}$ & $\mathrm{CR}$ & AVE \\
\hline 1. $E S H$ & & & & 0.772 & 0.772 & 0.530 \\
\hline ESH-1 & 0.752 & & Fixed & & & \\
\hline ESH-2 & 0.709 & & 7.546 & & & \\
\hline ESH-3 & 0.722 & & 7.666 & & & \\
\hline 2. KGIP & & & & 0.803 & 0.803 & 0.505 \\
\hline KGIP-1 & 0.723 & & Fixed & & & \\
\hline KGIP-2 & 0.713 & & 7.317 & & & \\
\hline KGIP-3 & 0.696 & & 7.176 & & & \\
\hline KGIP-4 & 0.709 & & 7.291 & & & \\
\hline 3. $K G B$ & & & & & 0.826 & 0.616 \\
\hline Environmental & & 0.661 & Fixed & 0.850 & & \\
\hline KGB-1 & 0.826 & & fixed & & & \\
\hline KGB-2 & 0.823 & & 10.049 & & & \\
\hline KGB-3 & 0.779 & & 9.593 & & & \\
\hline Social & & 0.792 & 5.349 & $\left(0.668^{* *}\right)$ & & \\
\hline KGB-4 & 0.772 & & Fixed & & & \\
\hline KGB-5 & 0.865 & & 8.193 & & & \\
\hline Economic & & 0.886 & 5.791 & $(0.721 * *)$ & & \\
\hline KGB-6 & 0.821 & & Fixed & & & \\
\hline KGB-7 & 0.878 & & 10.039 & & & \\
\hline 4. $P L G$ & & & & $(0.518 * *)$ & 0.692 & 0.533 \\
\hline PLG-1 & 0.811 & & Fixed & & & \\
\hline PLG-2 & 0.638 & & 6.415 & & & \\
\hline 5. $A L$ & 1.000 & & Fixed & & & \\
\hline 6.JS & & & & & & \\
\hline
\end{tabular}

Table 1.

Scale items and factor loadings for the study variables
Notes: $1^{\text {st }} \mathrm{SFL}=$ first-order standard factor loading; $2^{\text {nd }}=$ second-order; $\mathrm{CA}=$ Cronbach's-alpha. $0=$ internal correlations; $* *=p \leq 0.01$, two-tailed; $t=$ critical ratio; $\mathrm{CR}=$ composite reliability; $\mathrm{AVE}=$ average variance extraction
Table 2.

Descriptive statistics and Pearson correlation analysis

\begin{tabular}{lcccccccc}
\hline Variables & Mean & SD & \multicolumn{1}{c}{1} & \multicolumn{1}{c}{2} & \multicolumn{1}{c}{3} & \multicolumn{1}{c}{4} & 5 & 6 \\
\hline 1. ESH & 3.033 & 0.999 & 0.728 & $0.442^{* *}$ & $0.575^{* *}$ & $0.531^{* *}$ & $0.226^{* *}$ & $/$ \\
2. KGIP & 2.908 & 0.892 & $0.443^{* *}$ & 0.711 & $0.365^{* *}$ & $0.456^{* *}$ & $0.227^{* *}$ & $/$ \\
3. $K G B$ & 2.927 & 0.923 & $0.576^{* *}$ & $0.366^{* *}$ & 0.785 & $0.501^{* *}$ & $0.169^{*}$ & $/$ \\
4. $P L G$ & 3.046 & 1.011 & $0.532^{* *}$ & $0.457^{* *}$ & $0.502^{* *}$ & 0.727 & $0.285^{* *}$ & $/$ \\
5. $A L$ & 2.831 & 1.010 & $0.228^{* *}$ & $0.229^{* *}$ & $0.171^{*}$ & $0.286^{* *}$ & $/$ & $/$ \\
6. JS & 3.556 & 1.088 & 0.035 & -0.040 & 0.085 & -0.049 & 0.002 & $/$
\end{tabular}

Notes: Cross diagonals represent the SRAVE; $*=p \leq 0.05, * *=p \leq 0.01$, two-tailed. The italic are CMVadjusted correlation

MV after the survey (Liu et al., 2020). The other is to prepare a MV that is not theoretically correlated with at least one research variables before the survey (Malhotra et al., 2006). JS was selected as MV (Wanous et al., 1997). In Table 2, we chose the smallest correlation coefficient between MV and other variables (JS and AL: 0.002) to adjust the correlation coefficient and its significance (italic in Table 2). The original significant correlation coefficients did not decrease after adjustment, CMV will not seriously affect our study. 
The hypotheses testing is divided into multiple mediation and moderation (including moderated mediation) analysis. For mediation analysis, causal steps approach has been questioned because of its lower testing power (Edwards and Lambert, 2007). The bootstrap estimation method directly examines the product term $(\mathrm{a} * \mathrm{~b})$ in casual step approach to make it have higher testing power. In dealing with the influence mechanism (such as mediation analysis), the bootstrap estimation method is not inferior to the structural equation model (SEM) (Hayes et al., 2017) and this method has been widely used in academia (Fisher et al., 2012; Liu et al., 2020). Therefore, the bootstrap estimation method was used (Zhao et al., 2010), we use PROCESS macro version 3.1 based on SPSS 23 to conduct bootstrap estimation.

We set bootstrap of 2,000 repeated samples and the confidence interval (CI) was set at $95 \%$. The sampling method adopted the bias-corrected percentile, if zero was not included between lower and upper CI, the effect is significant (Hayes and Rockwood, 2020). According to Table 3, H1, $H 2 a$ and $H 2 b$ are supported. Meanwhile, the direct effect was significant, indicating that the mediation effect is partially mediation.

For moderation analysis, hierarchical regression [OLS estimation method for testing H3a, H3b, H4a, H4b (using SPSS 23)] (Liu et al., 2019a; Zhu and Sarkis, 2007) and bootstrap approach (for testing $H 3$ and $H 4$ ) were used. The hierarchical regression results are shown in Table 4 (only shown in the final step: Step 3). Model 1 represents the moderating effect of $A L$ on the relationship between $E S H$ and KGIP. The coefficient of $E S H^{*} A L$ was neither significant nor was $\mathrm{F}$ for the step significant and $R^{2}$ was not significantly improved, indicating that moderating effect is not significant. Similarly, for Models $2-4, A L$ has no significant moderating effect on the relationship between ESH and KGIP, KGIP and PLG. However, $A L$ has moderating effect on the relationship between $E S H$ and $K G B, K G B$ and $P L G$. Therefore, $H 3 a$ and $H 3 b$ are not supported while $H 4 a$ and $H 4 b$ are supported.

The results of bootstrap estimation (for moderated mediation analysis) are shown in Table 5. The mediation effect (mediator: $K G I P$ ) was significant at high and medium levels of $A L$, and the mediation effect decreased with the decrease of $A L$ level. Therefore, $A L$ plays a positive role in moderating this mediation effect, thus, $H 3$ is not supported. Similarly, $A L$ plays a negative role in moderating the mediation effect (mediator: $K G B$ ), thus, $H 4$ is supported.

\section{Discussion}

\subsection{Discussion on empirical results}

The results suggest that both mediating variables show the effects of partial mediation. Thus, in addition to the factor of organizational knowledge, there may be other internal

\begin{tabular}{lrrrrl}
\hline & & & & \multirow{2}{*}{$95 \%$ CI } & \\
Mediation model & Effect & SE & Lower & Upper & Hypotheses \\
\hline Total effect & 0.542 & 0.074 & 0.396 & 0.689 & \\
Direct effect & 0.288 & 0.088 & 0.114 & 0.463 & H1: supported \\
Indirect effects-total & 0.254 & 0.064 & 0.132 & 0.379 & \\
Indirect effects-KGIP & 0.111 & 0.037 & 0.041 & 0.186 & $H 2 a$ : supported \\
Indirect effects-KGB & 0.143 & 0.051 & 0.045 & 0.249 & H2b: supported \\
Indirect effect contrast (KGIP vs KGB) & -0.032 & 0.061 & -0.158 & 0.084 &
\end{tabular}

Notes: $\mathrm{SE}=$ Standard error; $\mathrm{CI}$ = Confidence interval; the effects are non-standardized effects

Table 3.

Mediation effects of $K G I P$ and $K G B$

organizational learning perspective

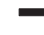




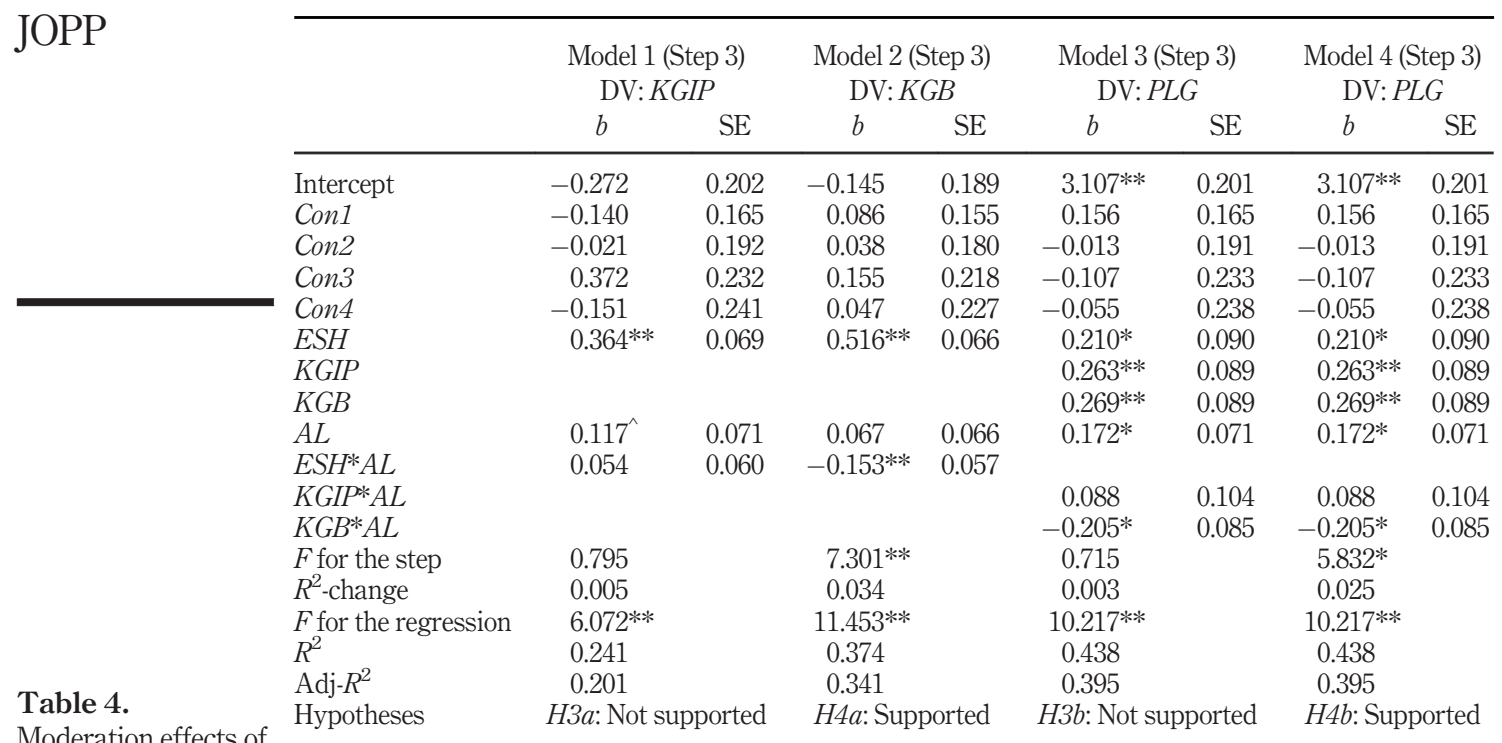
eration effects of $A L$

Notes: ${ }^{\wedge}=p \leq 0.1, *=p \leq 0.05, * *=p \leq 0.01$, two-tailed; each model only represent step 3

Table 5.

Conditional process of $E S H$ on $P L G$ at different levels of $A L$

\begin{tabular}{|c|c|c|c|c|c|c|}
\hline \multirow[b]{2}{*}{ Moderated mediation model } & \multirow[b]{2}{*}{ Moderate } & \multicolumn{5}{|c|}{$95 \% \mathrm{CI}$} \\
\hline & & Effect & $\mathrm{SE}$ & Lower & Upper & Hypotheses \\
\hline $\begin{array}{l}\text { At different levels of } A L \text {, the effect of } \\
E S H \text { on } P L G \text { via } K G I P\end{array}$ & & & & & & $\begin{array}{l}H 3 a: \text { not } \\
\text { supported }\end{array}$ \\
\hline$-1 \mathrm{SD}(A L)$ & -1.010 & 0.054 & 0.052 & -0.036 & 0.176 & \\
\hline Mean & 0 & 0.096 & 0.036 & 0.036 & 0.172 & \\
\hline$+1 \mathrm{SD}$ & 1.010 & 0.147 & 0.020 & 0.020 & 0.313 & \\
\hline $\begin{array}{l}\text { At different levels of } A L \text {, the effect of } \\
E S H \text { on } P L G \text { via } K G B\end{array}$ & & & & & & $\begin{array}{l}H 3 b: \\
\text { supported }\end{array}$ \\
\hline$-1 \mathrm{SD}(A L)$ & -1.010 & 0.320 & 0.085 & 0.143 & 0.489 & \\
\hline Mean & 0 & 0.139 & 0.048 & 0.045 & 0.233 & \\
\hline$+1 \mathrm{SD}$ & 1.010 & 0.023 & 0.047 & -0.074 & 0.118 & \\
\hline
\end{tabular}

Notes: $\mathrm{SE}=$ Standard error; $\mathrm{CI}=$ Confidence interval; $E S H, K G I P, K G B, A L$ has been mean-centered before calculation; the effects are non-standardized effects

factors acting as mediators, such as top management support (Brammer and Walker, 2011; Delmonico et al., 2018), training (Aragão and Jabbour, 2017) and affective commitment to change (Grandia and Voncken, 2019). This study compared the two mediating variables (KGIP and $K G B$ ). The difference of their mediating effects is not significant. This indicates that the two factors are similarly important, which updates the previous view that knowledge of policies is the most important factor (Liu et al., 2019a). It highlights the importance of the knowledge of GPP benefits, as we have newly proposed. 
$H 3 a$ and $H 3 b$ are not supported. One possible explanation is that even if a public sector has its own GPP implementation rules, it should be guided by national policies. The green items lists and certification bodies can provide a reference for public sectors to formulate higher GPP implementation rules. Also, public sectors can reduce the possibility of punishment for violations by improving their knowledge of national-level policies (Nadeem et al., 2017).

Surprisingly, the bootstrap results show that the administrative level of public sectors significantly and positively moderates the mediating effect of knowledge of GPP policies (Table 5). This once again shows that the bootstrap method has higher testing power (Edwards and Lambert, 2007). This means that although H3a and H3b's tests are not significant, H3's testing can still be significant (although the moderation direction is opposite to the hypothesis put forth in this study).

A reasonable explanation is that it may be caused by the unique public procurement agency mechanism of China. In China, public sectors can not only purchase by themselves but also entrust the procurement to agencies (Standing Committee of the National People's Congress, 2014). Existing agencies can be divided into centralized procurement agencies (government procurement centers) and decentralized procurement agencies (social intermediary agencies) (Ministry of Finance, 2018). Many Chinese public sectors tend to choose agencies for procurement (Xu et al., 2016).

For higher-level public sectors, will pay more attention to their own procurement needs and tend to implement by themselves as they have more resources, such as time, professionals and procurement departments. In this case, they need to better understand the relevant policies to promote better GPP implementation. Also, higher-level public sectors may dominate the procurement even if they entrust it to the agencies. The agencies only need to assist them to complete the procurement, so higher-level public sectors need to fully understand the GPP implementation policies. Conversely, lower-level public sectors tend to choose agencies for improving procurement efficiency due to their limited resources (Liu et al., 2019b). When entrusting agencies, lower-level public sectors may only need to indicate their own procurement requirements and less participate or guide specific procurement details. The details of GPP implementation is likely to be handled by the agencies. Therefore, in this case, a lower-level public sector may not need to have in-depth knowledge of GPP implementation policies.

\subsection{Study contributions}

The theoretical contributions of this study mainly include the following four aspects.

First, this study uncovers the black box relationship between external stakeholder drivers and GPP practice from the perspective of OLT. This study develops an "outside to inside" theoretical model to better understand the influence mechanism from the perspective of organizational learning. This adds to existing knowledge (Roman, 2017; Walker and Brammer, 2009; Zhu et al., 2013a) and responds to Liu et al. (2019a)'s call for mediation analysis.

Second, this study explores the knowledge of GPP benefits based on the TBL. Although knowledge is considered to be an important factor (Sönnichsen and Clement, 2020), existing studies focus more on the knowledge of policies and ignore other knowledge (Ahsan and Rahman, 2017; Nadeem et al., 2017; Testa et al., 2012). The results show that knowledge of GPP benefits is equally important as knowledge of policies.

Third, this study explores the factor of administrative levels with the characteristics of Chinese public sectors. We extend the study of Liu et al. (2019b) by introducing administrative level as a moderator. In addition, this study identifies three external stakeholders for public 
sectors to implement GPP, adding existing literature (Ahsan and Rahman, 2017; Akenroye et al., 2013; Oruezabala and Rico, 2012; Zhu et al., 2013a).

\section{Conclusion}

This study focuses on the GPP practice of public sectors and develops a multiple mediation theoretical model from the perspective of organizational learning. It aims to uncover the black box of the influence mechanism between external stakeholder drivers and GPP practice and explore the moderating effect of administrative level in this process.

The results suggest that external stakeholder drivers have a positive relationship with GPP practice. Both the knowledge of GPP implementation policies and the knowledge of GPP benefits mediate this relationship. Also, this study shows that the administrative level of public sectors positively moderates the mediating effect produced by the knowledge of GPP implementation policies, and negatively moderates the mediating effect produced by the knowledge of GPP benefits. These findings answer our $R Q s$.

In addition, this study provides a comparison between new and previous GPP implementation policies in China in Appendix 1. In Appendix 2, this study also provides GPP implementation policies comparisons between China and EU. This will facilitate international researchers to better understand China's GPP policies.

This study also has certain limitations. The stakeholder theory and organizational learning theory are relatively incomprehensive for interpreting the GPP practice. Meanwhile, the survey sample is small and the sampling method may also be biased. Therefore, the applicability of the conclusions requires further study. In addition, because this study focuses on the influence mechanism, the three major external stakeholders are studied as a single concept. Future research will be more specific and explore the impact of each of these three external stakeholders on GPP practices to find whether a particular external stakeholder is more important or relevant, and the interactions between them. Furthermore, the size of public sectors is a similar factor to administrative level (Liu et al., 2019b) and the size of public sectors is widely explored in EU (Michelsen and de Boer, 2009; Testa et al., 2012). Although this study is based on China, we call for similar studies to be conducted in other institutional contexts.

\subsection{Practice and policy implications}

For public sectors. First, public sectors should increase the knowledge of GPP benefits. Public sectors can use internal training (Aragão and Jabbour, 2017) to ensure that the knowledge of GPP-related benefits is deeply embedded in the members of the sectors. Public sectors can also invite experts from developed countries to share knowledge of GPP benefits and refer to the publicity methods of developed countries (European Commission, 2019). Second, public sectors should reduce their dependence on social intermediary agencies. Excessive use of agencies may lead to agency problems. That is, agencies may do harmful to the clients' interests for their own gain (Bebchuk and Fried, 2003). It results in the difficulty of better GPP practice. As a commercial organization, the operation goal of an agency is to maximize profits. Hence, it may focus more on its own interests and ignore public sectors' higher requirements pertaining to the environment. For example, agencies may accept bribes from potential suppliers (Tadelis, 2012), to ignore objective evaluation criteria, including environmental criteria, in the process of selecting suppliers.

For policymakers. Local governments should take effective measures to drive better GPP practice in public sectors. First, local governments can increase the budgets of public sectors. Second, local governments should strengthen the management of GPP practice in public sectors, such as formulating stricter local GPP policies or assigning GPP as an important task to top managers of public sectors. Finally, local governments should 
strengthen the supervision of GPP implementation through special inspections and other means. Also, local governments should more reasonably allocate resources among public sectors at different administrative levels. Although administrative levels are difficult to change, resource availability at the same administrative level can be adjusted.

\section{References}

Adams, R.B., Licht, A.N. and Sagiv, L. (2011), "Shareholders and stakeholders: how do directors decide?”, Strategic Management Journal, Vol. 32 No. 12, pp. 1331-1355.

Ahsan, K. and Rahman, S. (2017), "Green public procurement implementation challenges in Australian public healthcare sector", Journal of Cleaner Production, Vol. 152, pp. 181-197.

Akenroye, T.O., Oyegoke, A.S. and Eyo, A.B. (2013), "Development of a framework for the implementation of green public procurement in Nigeria”, International Journal of Procurement Management, Vol. 6 No. 1, pp. 1-23.

Alhola, K., Ryding, S.O., Salmenperä, H. and Busch, N.J. (2019), "Exploiting the potential of public procurement: opportunities for circular economy", Journal of Industrial Ecology, Vol. 23 No. 1, pp. 96-109.

Aragão, C.G. and Jabbour, C.J.C. (2017), "Green training for sustainable procurement? Insights from the Brazilian public sector”, Industrial and Commercial Training, Vol. 49 No. 1, pp. 48-54.

Argote, L. and Miron-Spektor, E. (2011), "Organizational learning: from experience to knowledge", Organization Science, Vol. 22 No. 5, pp. 1123-1137.

Ayee, J.R.A. (2013), "The political economy of the creation of districts in Ghana”, Journal of Asian and African Studies, Vol. 48 No. 5, pp. 623-645.

Bala, A., Muñoz, P., Rieradevall, J. and Ysern, P. (2008), "Experiences with greening suppliers. the Universitat Autonoma de Barcelona”, Journal of Cleaner Production, Vol. 16 No. 15, pp. 1610-1619.

Bebchuk, L.A. and Fried, J.M. (2003), "Executive compensation as an agency problem”, Journal of Economic Perspectives, Vol. 17 No. 3, pp. 71-92.

Bouwer, M. Jonk, M. Berman, T. Bersani, R. Lusser, H. Nappa, V. Nissinen, A. Parikka, K. Szuppinger, P. and Viganò, C. (2011), "Green public procurement in Europe 2006 - conclusions and recommendations", available at: http://ec.europa.eu/environment/gpp/pdf/take_5.pdf (accessed 9 July 2020).

Boykoff, M.T. and Boykoff, J.M. (2007), "Climate change and journalistic norms: a case-study of US mass-media coverage”, Geoforum, Vol. 38 No. 6, pp. 1190-1204.

Brammer, S. and Walker, H. (2011), "Sustainable procurement in the public sector: an international comparative study", International Journal of Operations and Production Management, Vol. 31 No. 4, pp. 452-476.

Brødsgaard, K.E. (2002), "Institutional reform and the Bianchi system in China", The China Quarterly, Vol. 170, pp. 361-386.

Brown, P.H. and Theoharides, C. (2009), "Health-seeking behavior and hospital choice in China's new cooperative medical system", Health Economics, Vol. 18, pp. 47-64.

Burja, A. (2009), "Using green public procurement for sustainable consumption and production", Journal for European Environmental and Planning Law, Vol. 6 No. 3, pp. 319-338.

Cavaleri, S.A. (2004), "Leveraging organizational learning for knowledge and performance", The Learning Organization, Vol. 11 No. 2, pp. 159-176.

Cerutti, A.K., Contu, S., Ardente, F., Donno, D. and Beccaro, G.L. (2016), "Carbon footprint in green public procurement: policy evaluation from a case study in the food sector", Food Policy, Vol. 58, pp. 82-93. 
Chan, K.W. (2010), "Fundamentals of China's urbanization and policy”, The China Review, Vol. 10 No. 1, pp. 63-94.

Cheng, W., Appolloni, A., D’Amato, A. and Zhu, Q. (2018), "Green public procurement, missing concepts and future trends-a critical review”, Journal of Cleaner Production, Vol. 176, pp. 770-784.

Churchill, G.A. (1979), “A paradigm for developing better measures of marketing constructs”, Journal of Marketing Research, Vol. 16 No. 1, pp. 64-73.

Crossan, M.M., Lane, H.W. and White, R.E. (1999), "An organizational learning framework: from intuition to institution", Academy of Management Review, Vol. 24 No. 3, pp. 522-537.

Crossan, M.M., Maurer, C.C. and White, R.E. (2011), "Reflections on the 2009 AMR decade award: do we have a theory of organizational learning?", Academy of Management Review, Vol. 36 No. 3, pp. 446-460.

Dai, J., Montabon, F.L. and Cantor, D.E. (2014), "Linking rival and stakeholder pressure to green supply management: mediating role of top management support", Transportation Research Part E: Logistics and Transportation Review, Vol.71, pp. 173-187.

Darnall, N. (2006), "Why firms mandate ISO 14001 certification", Business and Society, Vol. 45 No. 3, pp. 354-381.

De Giacomo, M.R., Testa, F., Iraldo, F. and Formentini, M. (2019), "Does green public procurement lead to life cycle costing (LCC) adoption?”, Journal of Purchasing and Supply Management, Vol. 25 No. 3, p. 100500.

Delmonico, D., Jabbour, C.J.C., Pereira, S.C.F., de Sousa Jabbour, A.B.L., Renwick, D.W.S. and Thomé, A. M.T. (2018), "Unveiling barriers to sustainable public procurement in emerging economies: evidence from a leading sustainable supply chain initiative in Latin America", Resources, Conservation and Recycling, Vol. 134, pp.70-79.

Diófási-Kovács, O. and Valkó, L. (2015), "Furthering sustainable development: the implementation of green procurement in Central and Eastern Europe: methods and experiences from Hungarian public and private organizations", Problemy ekorozwoju-Problems of Sustainable Development, Vol. 10 No. 2, pp. 115-126.

Dodgson, M. (1993), "Organizational learning: a review of some literatures", Organization Studies, Vol. 14 No. 3, pp. 375-394.

Dou, Y., Sarkis, J. and Bai, C. (2014), "Government green procurement: a Fuzzy-DEMATEL analysis of barriers", in Kahraman, C. and Öztayşi, B. (Eds), Supply Chain Management under Fuzziness, Springer. Heidelberg, Germany, pp. 567-589.

$\mathrm{Du}, \mathrm{Y}$. (2016), "De-administration in colleges and universities is imperative", Guangming Daily. (in Chinese)

Du, Y., Zhang, W., Lei, F., Yu, X., Li, Z., Liu, X., Ni, Y., Deng, L. and Ji, M. (2020), "Long-term survival after nasopharyngeal carcinoma treatment in a local prefecture-level hospital in Southern China”, Cancer Management and Research, Vol. 12, pp. 1329-1338.

Edwards, J.R. and Lambert, L.S. (2007), "Methods for integrating moderation and mediation: a general analytical framework using moderated path analysis", Psychological Methods, Vol. 12 No. 1, pp. 1-22.

Elkington, J. (1998), "Partnerships from cannibals with forks: the triple bottom line of $21^{\text {st }}$-century business”, Environmental Quality Management, Vol. 8 No. 1, pp. 37-51.

European Commission (2016), Buying Green! a Handbook on Environmental Public Procurement, 3rd ed., European Commission, Brussels, Belgium.

European Commission (2019), "Benefits of GPP”, available at: https://ec.europa.eu/environment/gpp/ benefits_en.htm (accessed 9 July 2020).

Fiol, C.M. and Lyles, M.A. (1985), "Organizational learning”, Academy of Management Review, Vol. 10 No. 4, pp. 803-813. 
Fisher, D.M., Bell, S.T., Dierdorff, E.C. and Belohlav, J.A. (2012), "Facet personality and surface-level diversity as team mental model antecedents: implications for implicit coordination", Journal of Applied Psychology, Vol. 97 No. 4, pp. 825-841.

Fornell, C. and Larcker, D.F. (1981), "Evaluating structural equation models with unobservable variables and measurement error", Journal of Marketing Research, Vol. 18 No. 3, pp. 29-50.

Freeman, R.E. (1984), Strategic Management: A Stakeholder Approach, Pitman, Marshfield.

Gelderman, C.J., Semeijn, J. and Vluggen, R. (2017), "Development of sustainability in public sector procurement”, Public Money and Management, Vol. 37 No. 6, pp. 435-442.

General Office of the CPC Central Committee (2019), "Notice on solving prominent problems of formalism and reducing the burden on the grassroots", available at: www.gov.cn/zhengce/201903/11/content_5372964.htm (accessed 9 July 2020).

Geng, Y. and Doberstein, B. (2008), "Greening government procurement in developing countries: building capacity in China", Journal of Environmental Management, Vol. 88 No. 4, pp. 932-938.

Giannakis, M., Dubey, R., Vlachos, I. and Ju, Y. (2019), "Supplier sustainability performance evaluation using the analytic network process", Journal of Cleaner Production, Vol. 247, p. 119439.

Giunipero, L.C., Hooker, R.E. and Denslow, D. (2012), "Purchasing and supply management sustainability: drivers and barriers", Journal of Purchasing and Supply Management, Vol. 18 No. 4, pp. 258-269.

Govindan, K., Khodaverdi, R. and Jafarian, A. (2013), "A fuzzy multi criteria approach for measuring sustainability performance of a supplier based on triple bottom line approach", Journal of Cleaner Production, Vol. 47, pp. 345-354.

Govindan, K., Rajendran, S., Sarkis, J. and Murugesan, P. (2015), "Multi criteria decision making approaches for green supplier evaluation and selection: a literature review", Journal of Cleaner Production, Vol. 98 No. 98, pp. 66-83.

Grandia, J. (2016), "Finding the missing link: examining the mediating role of sustainable public procurement behavior", Journal of Cleaner Production, Vol. 124, pp. 183-190.

Grandia, J. (2018), "Public procurement in Europe", in Ongaro, E. and Van Thiel, S. (Eds), The Palgrave Handbook of Public Administration and Management in Europe, Palgrave Macmillan. London, pp. 363-380.

Grandia, J. and Meehan, J. (2017), "Public procurement as a policy tool: using procurement to reach desired outcomes in society", International Journal of Public Sector Management, Vol. 30 No. 4, pp. 302-309.

Grandia, J. and Voncken, D. (2019), "Sustainable public procurement: the impact of ability, motivation, and opportunity on the implementation of different types of sustainable public procurement", Sustainability, Vol. 11 No. 19, p. 5215.

Gunningham, N., Kagan, R.A. and Thornton, D. (2004), "Social license and environmental protection: why businesses go beyond compliance", Law and Social Inquiry, Vol. 29 No. 2, pp. 307-341.

Günther, E. and Scheibe, L. (2006), "The hurdle analysis. A self-evaluation tool for municipalities to identify, analyse and overcome hurdles to green procurement", Corporate Social Responsibility and Environmental Management, Vol. 13 No. 2, pp. 61-77.

Hair, J.F., Black, W.C., Babin, B.J. and Anderson, R.E. (2010), Multivariate Data Analysis, 7th ed., Prentice-Hall, Upper Saddle River, NJ.

Hassan, M. and Sheely, R. (2017), "Executive-legislative relations, party defections, and lower level administrative unit proliferation: evidence from Kenya”, Comparative Political Studies, Vol. 50 No. 12, pp. 1595-1631.

Hasselbalch, J., Costa, N. and Blecken, A. (2014), "Examining the relationship between the barriers and current practices of sustainable procurement: a survey of UN organizations", Journal of Public Procurement, Vol. 14 No. 3, pp. 361-394. 
Hayes, A.F. and Rockwood, N.J. (2020), "Conditional process analysis: concepts, computation, and advances in the modeling of the contingencies of mechanisms", American Behavioral Scientist, Vol. 64 No. 1, pp. 19-54.

Hayes, A.F., Montoya, A.K. and Rockwood, N.J. (2017), "The analysis of mechanisms and their contingencies: PROCESS versus structural equation modeling", Australasian Marketing Journal, Vol. 25 No. 1, pp. 76-81.

Heckathorn, D.D. (2002), "Respondent-driven sampling II: deriving valid population estimates from chain-referral samples of hidden populations", Social Problems, Vol. 49 No. 1, pp. 11-34.

Hefner, M.A. (2014), "What is an organization that it may learn? Reconstructing the individualorganizational tension in learning and knowledge", available at: http://pdfs.semanticscholar.org/ 1e10/d8de5ca3b0f8317e12f21cf65fce902f3e8a.pdf (accessed 9 July 2020).

Henderson, J.V. Quigley, J. and Lim, E. (2009), "Urbanization in China: Policy issues and options”, available at: www.econ.brown.edu/Faculty/henderson/FinalFinalReport-2007050221.pdf (accessed 9 July 2020).

Ho, L.W., Dickinson, N.M. and Chan, G.Y. (2010), "Green procurement in the Asian public sector and the Hong Kong private sector", Natural Resources Forum, Vol. 34 No. 1, pp. 24-38.

Hollos, D., Blome, C. and Foerstl, K. (2012), "Does sustainable supplier co-operation affect performance? Examining implications for the triple bottom line", International Journal of Production Research, Vol. 50 No. 11, pp. 2968-2986.

Ihamäki, V. van-Ooij, E. and van-der-Panne, S. (2014), "Green public procurement in the European Union and the use of eco-labels", available at: www.maastrichtuniversity.n1/sites/default/files/2014/ Green_Public_Procurement_in_the_European_Union_and_the_Use_of_Eco-Labels.pdf (accessed 9 July 2020).

Inkpen, A. (1998), “Learning, knowledge acquisition, and strategic alliances”, European Management Journal, Vol. 16 No. 2, pp. 223-229.

Jenks, S.S. and Wright, D.S. (1993), "An agency-level approach to change in the administrative functions of American state governments", State and Local Government Review, Vol. 25 No. 2, pp. 78-86.

Kannan, D., Khodaverdi, R., Olfat, L., Jafarian, A. and Diabat, A. (2013), "Integrated fuzzy multi criteria decision making method and multi-objective programming approach for supplier selection and order allocation in a green supply chain”, Journal of Cleaner Production, Vol. 47, pp. 355-367.

Kline, R.B. (2005), Principles and Practice of Structural Equation Modeling, The Guilford Press, New York, NY.

Krammer, S.M.S. (2013), "Partner selection in international technological alliances: the role of institutional differences, historical ties and size of the focal firm", 35th DRUID Celebration Conference, Barcelona, Spain.

Lee, A.H., Kang, H., Hsu, C. and Hung, H. (2009), “A green supplier selection model for high-tech industry”, Expert Systems with Applications, Vol. 36 No. 4, pp. 7917-7927.

Li, H., Wei, Y.D., Liao, F.H. and Huang, Z. (2015), “Administrative hierarchy and urban land expansion in transitional China", Applied Geography, Vol. 56, pp. 177-186.

Li, L. and Geiser, K. (2005), "Environmentally responsible public procurement and its implications for integrated product policy", Journal of Cleaner Production, Vol. 13 No. 7, pp. 705-715.

Lian, P.C. and Laing, A.W. (2004), "Public sector purchasing of health services: a comparison with private sector purchasing", Journal of Purchasing and Supply Management, Vol. 10 No. 6, pp. 247-256.

Lin, C. and Ho, Y. (2011), "Determinants of green practice adoption for logistics companies in China", Journal of Business Ethics, Vol. 98 No. 1, pp. 67-83.

Lindell, M.K. and Whitney, D.J. (2001), "Accounting for common method variance in cross-sectional research designs”, Journal of Applied Psychology, Vol. 86 No. 1, pp. 114-121. 
Lindner, F. and Wald, A. (2011), "Success factors of knowledge management in temporary organizations", International Journal of Project Management, Vol. 29 No. 7, pp. 877-888.

Liu, J., Shi, B., Xue, J. and Wang, Q. (2019a), "Improving the green public procurement performance of Chinese local governments: from the perspective of officials' knowledge”, Journal of Purchasing and Supply Management, Vol. 25 No. 3, p. 100501.

Liu, J., Xue, J., Yang, L. and Shi, B. (2019b), "Enhancing green public procurement practices in local governments: Chinese evidence based on a new research framework", Journal of Cleaner Production, Vol. 211, pp. 842-854.

Liu, J., Liu, Y. and Yang, L. (2020), "Uncovering the influence mechanism between top management support and green procurement: the effect of green training", Journal of Cleaner Production, Vol. 251, p. 119674.

Loader, K. (2018), "Small-and medium-sized enterprises and public procurement: a review of the UK coalition government's policies and their impact”, Environment and Planning C: Politics and Space, Vol. 36 No. 1, pp. 47-66.

McMurray, A.J., Islam, M.M., Siwar, C. and Fien, J. (2014), "Sustainable procurement in Malaysian organizations: practices, barriers and opportunities", Journal of Purchasing and Supply Management, Vol. 20 No. 3, pp. 195-207.

Malesky, E. (2009), "Gerrymandering-Vietnamese style: escaping the partial reform equilibrium in a nondemocratic regime", The Journal of Politics, Vol. 71 No. 1, pp. 132-159.

Malhotra, N.K., Kim, S.S. and Patil, A. (2006), "Common method variance in is research: a comparison of alternative approaches and a reanalysis of past research", Management Science, Vol. 52 No. 12, pp. 1865-1883.

Mélon, L. (2020), "More than a nudge? Arguments and tools for mandating green public procurement in the EU", Sustainability, Vol. 12 No. 3, p. 988.

Michelsen, O. and de Boer, L. (2009), "Green procurement in Norway; a survey of practices at the municipal and county level”, Journal of Environmental Management, Vol. 91 No. 1, pp. 160-167.

Mimba, N.P.S., van-Helden, G.J. and Tillema, S. (2013), "The design and use of performance information in Indonesian local governments under diverging stakeholder pressures", Public Administration and Development, Vol. 33 No. 1, pp. 15-28.

Ministry of Finance (2017), "Decree no. 87: measures for the administration of bidding for government procurement of goods and services", available at: www.ccgp.gov.cn/zcfg/mofgz/201707/ t20170718_8541199.shtml (accessed 9 July 2020).

Ministry of Finance (2018), "Interim measures for the administration of government procurement agencies", available at: www.gov.cn:8080/gongbao/content/2018/content_5301866.htm (accessed 9 July 2020).

Ministry of Finance (2019), "Notice on adjusting and optimizing the government procurement execution mechanism of energy-saving products and environmental labeling products", available at: www. ccgp.gov.cn/zcfg/mof/201902/t20190213_11628855.htm (accessed 9 July 2020).

Nadeem, S., Mohamad, M.H., Abdullah, N. and Halim, N.A. (2017), "Driving indicators for implementation of sustainable procurement behavior and practices", European Academic Research, Vol. 4 No. 11, pp. 9792-9820.

Nakao, T. (1993), "Market share, advertising, R\&D, and profitability: an empirical analysis of leading industrial firms in Japan”, Review of Industrial Organization, Vol. 8 No. 3, pp. 315-328.

National Bureau of statistics (2020), "The data of annual report", available at: https://data.stats.gov.cn/ easyquery.htm?cn $=\mathrm{C} 01$

Nybakk, E., Crespell, P. and Hansen, E. (2011), "Climate for innovation and innovation strategy as drivers for success in the wood industry: moderation effects of firm size, industry sector, and country of operation", Silva Fennica, Vol. 45 No. 3, pp. 415-430. 
O'Leary-Kelly, S.W.O. and Vokurka, R.J. (1998), "The empirical assessment of construct validity", Journal of Operations Management, Vol. 16 No. 4, pp. 387-405.

Oruezabala, G. and Rico, J.C. (2012), "The impact of sustainable public procurement on supplier management-the case of French public hospitals", Industrial Marketing Management, Vol. 41 No. 4, pp. 573-580.

Pacheco-Blanco, B. and Bastante-Ceca, M.J. (2016), "Green public procurement as an initiative for sustainable consumption. An exploratory study of Spanish public universities", Journal of Cleaner Production, Vol. 133, pp. 648-656.

Pepper, S. (1982), “China's universities: new experiments in socialist democracy and administrative reform-a research report", Modern China, Vol. 8 No. 2, pp. 147-204.

Pierskalla, J.H. (2016), "Splitting the difference? The politics of district creation in Indonesia", Comparative Politics, Vol. 48 No. 2, pp. 249-268.

Prajogo, D., Tang, A.K. and Lai, K.H. (2012), "Do firms get what they want from ISO 14001 adoption? An Australian perspective”, Journal of Cleaner Production, Vol. 33, pp. 117-126.

Preuss, L. (2009), "Addressing sustainable development through public procurement: the case of local government”, Supply Chain Management, Vol. 14 No. 3, pp. 213-223.

Rashman, L., Withers, E. and Hartley, J. (2009), "Organizational learning and knowledge in public service organizations: a systematic review of the literature", International Journal of Management Reviews, Vol. 11 No. 4, pp. 463-494.

Reijonen, H., Tammi, T. and Saastamoinen, J. (2016), "SMEs and public sector procurement: does entrepreneurial orientation make a difference?", International Small Business Journal: Researching Entrepreneurship, Vol. 34 No. 4, pp. 468-486.

Rietbergen, M.G. and Blok, K. (2013), "Assessing the potential impact of the $\mathrm{CO}_{2}$ performance ladder on the reduction of carbon dioxide emissions in The Netherlands", Journal of Cleaner Production, Vol. 52, pp. 33-45.

Roman, A.V. (2017), "Institutionalizing sustainability: a structural equation model of sustainable procurement in US public agencies", Journal of Cleaner Production, Vol. 143, pp. 1048-1059.

Rüdenauer, I. Dross, M. Eberle, U. Gensch, C.O. Graulich, K. Hünecke, K. Koch, Y. Möller, M. Quack, D. Seebach, D. Zimmer, W. Hidson, M. Defranceschi, P. and Tepper, P. (2007), "Costs and benefits of green public-general recommendations procurement in Europe", available at: https:/ec.europa. eu/environment/gpp/pdf/eu_recommendations_1.pdf (accessed 9 July 2020).

Sarkis, J., Gonzalez-Torre, P. and Adenso-Diaz, B. (2010), "Stakeholder pressure and the adoption of environmental practices: the mediating effect of training", Journal of Operations Management, Vol. 28 No. 2, pp. 163-176.

Sheng, M.L. and Chien, I. (2016), "Rethinking organizational learning orientation on radical and incremental innovation in high-tech firms", Journal of Business Research, Vol. 69 No. 6, pp. 2302-2308.

Simcoe, T. and Toffel, M.W. (2014), "Government green procurement spillovers: evidence from municipal building policies in California", Journal of Environmental Economics and Management, Vol. 68 No. 3, pp. 411-434.

Sönnichsen, S.D. and Clement, J. (2020), "Review of green and sustainable public procurement: towards circular public procurement", Journal of Cleaner Production, Vol. 245, p. 118901.

Standing Committee of the National People's Congress (2014), "Law of the people's republic of China on government procurement (revised)”, available at: http:/hcjy.zyhc.gov.cn/zwgk/jjxx/201805/ t20180524_25240094.html (accessed 9 July 2020).

Tadelis, S. (2012), "Public procurement design: lessons from the private sector", International Journal of Industrial Organization, Vol. 30 No. 3, pp. 297-302.

Testa, F., Iraldo, F., Frey, M. and Daddi, T. (2012), "What factors influence the uptake of GPP practices? New evidence from an Italian survey”, Ecological Economics, Vol. 82, pp. 88-96. 
Testa, F., Annunziata, E., Iraldo, F. and Frey, M. (2016), "Drawbacks and opportunities of green public procurement: an effective tool for sustainable production", Journal of Cleaner Production, Vol. 112, pp. 1893-1900.

Testa, F., Boiral, O. and Iraldo, F. (2018), "Internalization of environmental practices and institutional complexity: can stakeholders pressures encourage greenwashing?", Journal of Business Ethics, Vol. 147 No. 2, pp. 287-307.

Thomson, J. and Jackson, T. (2007), "Sustainable procurement in practice: lessons from local government", Journal of Environmental Planning and Management, Vol. 50 No. 3, pp. 421-444.

Tsai, W.T. (2017), "Green public procurement and green-mark products strategies for mitigating greenhouse gas emissions-experience from Taiwan", Mitigation and Adaptation Strategies for Global Change, Vol. 22 No. 5, pp. 729-742.

Wahid, F. (2012), "The green eProcurement infrastructure in the Indonesian public sector: its antecedents and impacts on the triple bottom line”, IEEE, 7-8 July 2012 Bandung, Indonesia. 2012 International Conference on Green and Ubiquitous Technology, pp. 66-70.

Walker, H. and Brammer, S. (2009), "Sustainable procurement in the United Kingdom public sector", Supply Chain Management: An International Journal, Vol. 14 No. 2, pp. 128-137.

Walker, H. and Brammer, S. (2012), "The relationship between sustainable procurement and eprocurement in the public sector", International Journal of Production Economics, Vol. 140 No. 1, pp. 256-268.

Walker, H. and Brammer, S. (2016), "Sustainable procurement, institutional context and top management commitment: an international public sector study", in Lindgreen, A., Maon, F., Vanhamme, J. and Sen, S. (Eds), Sustainable Value Chain Management: A Research Anthology, Routledge. London, pp. 19-38.

Walker, H., Di Sisto, L. and McBain, D. (2008), "Drivers and barriers to environmental supply chain management practices: lessons from the public and private sectors", Journal of Purchasing and Supply Management, Vol. 14 No. 1, pp. 69-85.

Wang, C., Qiao, Y. and Li, X. (2020a), “A systems approach for green public procurement implementation”, Journal of Public Procurement, Vol. 20 No. 3, pp. 287-311.

Wang, J. and Yeh, A.G. (2019), “Administrative restructuring and urban development in China: effects of urban administrative level upgrading”, Urban Studies, Vol. 57 No. 6, pp. 1201-1223.

Wang, K.L., Chiang, C. and Tung, C.M. (2012), "Integrating human resource management and knowledge management: from the viewpoint of core employees and organizational performance", International Journal of Organizational Innovation, Vol. 5 No. 1, pp. 109-137.

Wang, Q., Zhang, R. and Liu, J. (2020b), "Price/time/intellectual efficiency of procurement: uncovering the related factors in Chinese public authorities", Journal of Purchasing and Supply Management, Vol. 26 No. 3, p. 100622.

Wanous, J.P., Reichers, A.E. and Hudy, M.J. (1997), “Overall job satisfaction: how good are single-item measures?”, Journal of Applied Psychology, Vol. 82 No. 2, pp. 247-252.

Wei, H. (2015), "The administrative hierarchy and growth of urban scale in China", Chinese Journal of Urban and Environmental Studies, Vol. 3 No. 1, p. 1550001.

Wong, C. (2009), "Rebuilding government for the $21^{\text {st }}$-century: can China incrementally reform the public sector?”, The China Quarterly, Vol. 200, pp. 929-952.

$\mathrm{Xu}, \mathrm{S}$., Chu, C., Ju, M. and Shao, C. (2016), "System establishment and method application for quantitatively evaluating the green degree of the products in green public procurement", Sustainability, Vol. 8 No. 9, p. 941.

Yu, W. and Ramanathan, R. (2015), "An empirical examination of stakeholder pressures, green operations practices and environmental performance", International Journal of Production Research, Vol. 53 No. 21, pp. 6390-6407. 
Zhang, W., Derudder, B., Wang, J. and Witlox, F. (2020), "An analysis of the determinants of the multiplex urban networks in the Yangtze river Delta", Tijdschrift Voor Economische en Sociale Geografie, Vol. 111 No. 2, pp. 117-133.

Zhao, X., Lynch, J.G. and Chen, Q. (2010), "Reconsidering Baron and Kenny: myths and truths about mediation analysis", Journal of Consumer Research, Vol. 37 No. 2, pp. 197-206.

Zhu, Q. and Geng, Y. (2013), "Drivers and barriers of extended supply chain practices for energy saving and emission reduction among Chinese manufacturers", Journal of Cleaner Production, Vol. 40, pp. 6-12.

Zhu, Q. and Sarkis, J. (2007), "The moderating effects of institutional pressures on emergent green supply chain practices and performance", International Journal of Production Research, Vol. 45 Nos 18/19, pp. 4333-4355.

Zhu, Q., Geng, Y. and Sarkis, J. (2013a), "Motivating green public procurement in China: an individual level perspective", Journal of Environmental Management, Vol. 126, pp. 85-95.

Zhu, Q., Sarkis, J. and Lai, K.H. (2013b), "Institutional-based antecedents and performance outcomes of internal and external green supply chain management practices", Journal of Purchasing and Supply Management, Vol. 19 No. 2, pp. 106-117.

\section{Further reading}

Loader, K. (2013), "Is public procurement a successful small business support policy? A review of the evidence", Environment and Planning C: Government and Policy, Vol. 31 No. 1, pp. 39-55. 

policies has significant differences. The differences between China's GPP product list (Liu et al., 2019a) and items list (Ministry of Finance, 2019) are shown in Table A1. perspective

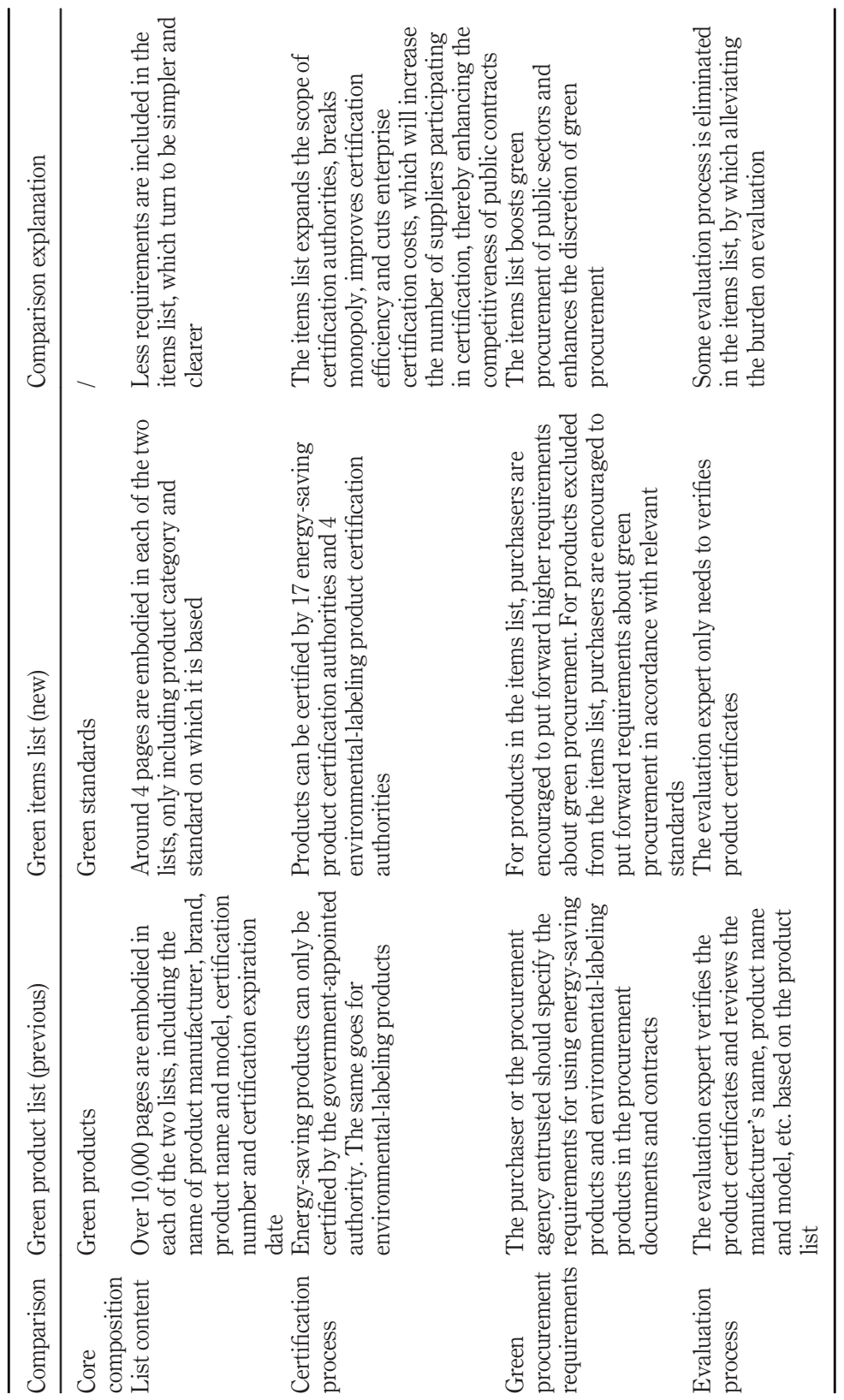

Table A1. China's new and previous GPP implementation policies 
Table A2.

China and EU GPP implementation policies comparison

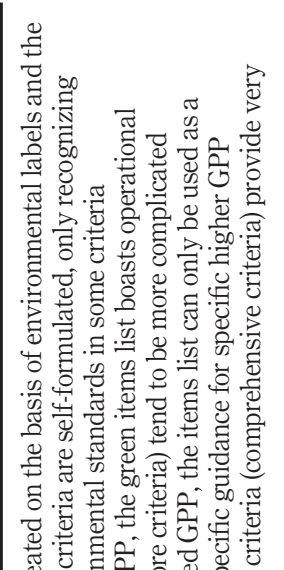

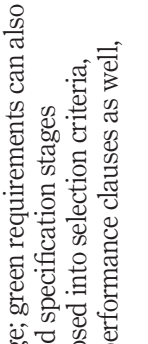

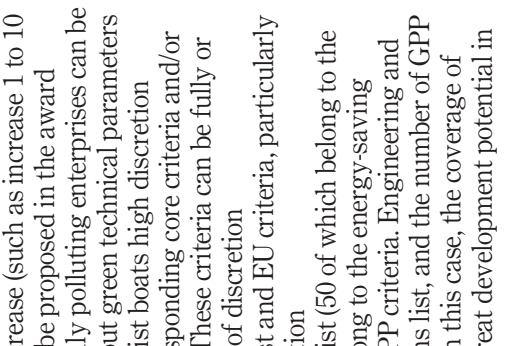

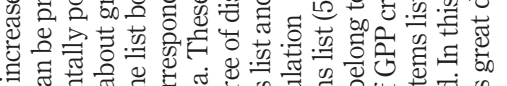

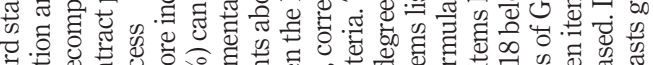

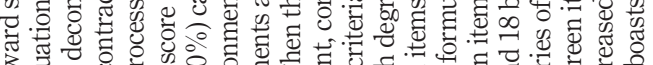

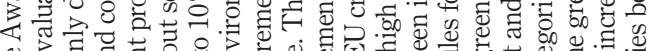

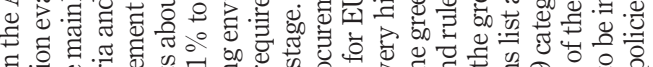

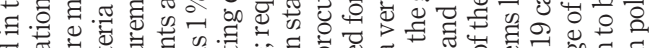

柁.

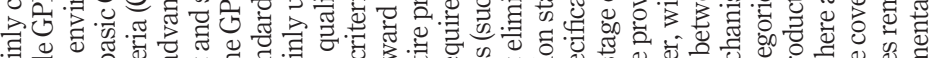

势

.

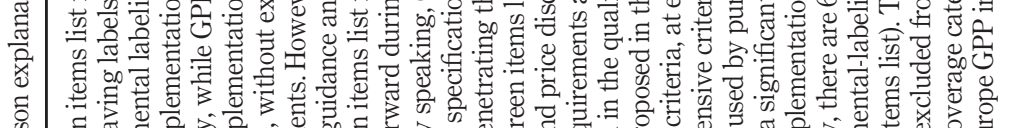

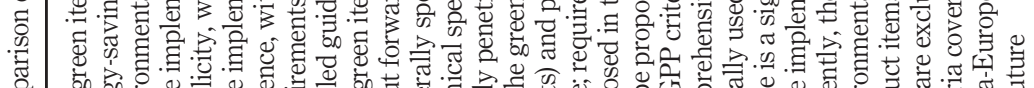

50 o 0.07 .

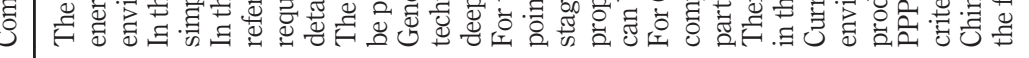

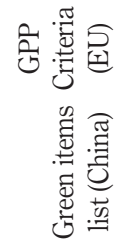

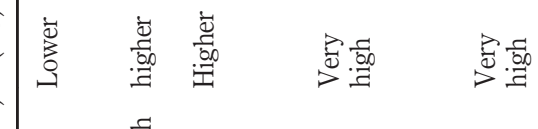

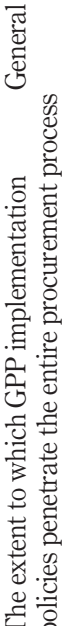

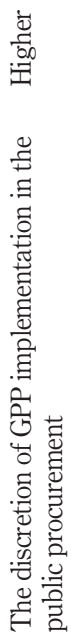

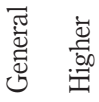

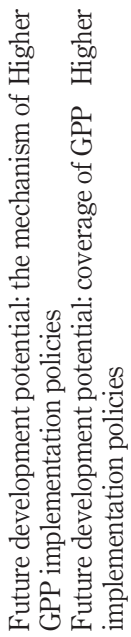




\begin{tabular}{|c|c|}
\hline Variable & Questions \\
\hline$E S H$ & $\begin{array}{l}\text { Please assess to what extent your } \\
\text { organization felt motivate/driver from the } \\
\text { following external stakeholders to } \\
\text { implement GPP ( } 1 \text { = not at all, } 5 \text { = very } \\
\text { strongly) }\end{array}$ \\
\hline$K G I P$ & $\begin{array}{l}\text { Please evaluate your organization's } \\
\text { understanding for the knowledge of GPP } \\
\text { implementation policies ( } 1=\text { never heard } \\
\text { about it, } 5=\text { very familiar })\end{array}$ \\
\hline
\end{tabular}

Items (Likert five-point scale)

Local government

Green leading suppliers

Society (Environmental-NGO, media, public)

Circular on adjusting and optimizing the implementation mechanism of government procurement of energy-saving products and environmental labeling products

Announcement on the publication of the list of certification institutions participating in the implementation of government procurement of energy-saving products and environmental labeling products

List of items for government procurement of energy-saving products

List of items for government procurement of environmental labeling products

Reduced pollution

Reduced energy and materials consumption understanding for the knowledge of GPP benefits $(1=$ never heard about it, $5=$ very familiar)

PLG Please evaluate your organization's implementation of GPP practice $(1=$ no extent whatsoever, $5=$ very great extent)
JS
$A L$
Please evaluate your overall job satisfaction N/A (single item measurement) $(1=$ very dissatisfied, 5 = very satisfied $)$
Please provide the administrative level of N/A (single item measurement) your public sector $(1=$ unit level, 2 = deputy section level, 3 = section level, $4=$ deputy division level, 5 = division level and above)

Reduced risks of environmental hazards Improved public image

Improved relations with stakeholders Guided green consumption and green production

Saved running cost

Our procurement function/department provides mandatory or/and priority measures in the tender evaluation process (qualification, specification and final selection/award) for environmentally friendly services and products based on life cycle assessment Our procurement function/department encourages/asks suppliers/vendors and contractors to commit to waste reduction goals and to emphasize environmental responsible practices

Table A3.

Measurement questions and items

\section{Corresponding author}

Junqi Liu can be contacted at: jqliu@my.swjtu.edu.cn

For instructions on how to order reprints of this article, please visit our website:

www.emeraldgrouppublishing.com/licensing/reprints.htm

Or contact us for further details: permissions@emeraldinsight.com 